\title{
Microphthalmia with single central incisor and hypopituitarism
}

\author{
Henry G Artman, Eric Boyden
}

\begin{abstract}
A patient is described with a new association of microphthalmia, single central incisor, and hypopituitarism believed to represent a holoprosencephaly malformation. In view of the genetic ramifications of this malformation and its variable manifestations, we would like to alert the clinician to consider holoprosencephaly whenever midline malformations are detected.
\end{abstract}

In 1977 Rappaport et $a l^{1}$ described the syndrome of 'monosuperocentroincivodontic dwarfism', characterised by a single central incisor associated with growth retardation. Since then a variety of midline facial defects have been described, including single central maxillary incisor associated with slow growth secondary to growth hormone deficiency. ${ }^{1-3}$ Holoprosencephaly, an anatomical defect of failure of division of the embryonic forebrain, is associated with midline facial defects and suggests that this condition might have a wide variety of clinical manifestations. The case described reports a newly delineated association of a single central incisor in a patient with microphthalmia and growth retardation as possible manifestations of holoprosencephaly.

\section{Case report}

The proband, a 5 year 1 month old female, was referred to the Department of Pediatrics, University of Nevada School of Medicine for evaluation of 'slow growth'. She was born at term, birth weight $2948 \mathrm{~g}$, to a 19 year old G2P1 female whose pregnancy was unremarkable; there was no exposure to alcohol or drugs. The proband's only pertinent past medical history included 'slow growth', periodic severe headaches requiring treatment with paracetamol (Tylenol),

Department of Pediatrics, University of Nevada School of Medicine, Brigham Building, Reno, Nevada 89557, USA.

H G Artman, E Boyden

Correspondence to Dr Artman. intermittent nasal congestion, and near complete blindness secondary to microphthalmia. Neuromotor development and intelligence were otherwise normal.

Family history was entirely negative including anosmia. Physical examination showed a small, well proportioned female with microphthalmia (figure). Her height was $82.5 \mathrm{~cm}$ and weight $8.8 \mathrm{~kg}$, both well below $3 \mathrm{SD}$ and at the 50th centile for an 18 month and 9 month old respectively. Additional findings included opaque corneas and a single central maxillary incisor. Laboratory assessment for thyroid function, electrolyte abnormalities, and serum glucose were normal. Urine osmolality showed normal concentrating ability and blood chromosome studies using banding techniques was normal. Radiological evaluation indicated a bone age of 2 years 5 months and CT scan showed a small sella turcica with a hypoplastic appearing pituitary gland. The optic chiasm and nerves appeared normal, as did the orbital sockets. A small bony ridge was noted in the roof of the hard palate. Magnetic resonance imaging of the brain was normal except for a diminished hypo-

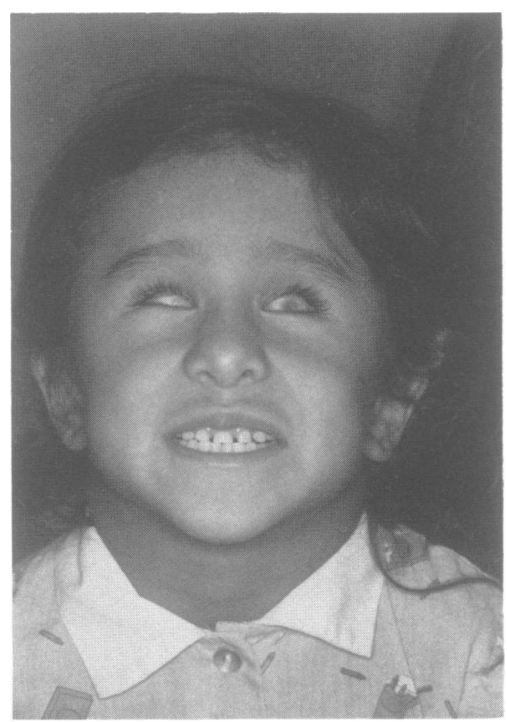

The proband aged $61 / 2$ years. Note single central maxillary incisor and opaque corneas. 
physeal stalk. Provocative stimulation tests for growth hormone, using clonidine $0.15 \mathrm{mg} / \mathrm{m}^{2}$, followed by $\mathrm{L}$ dopa $125 \mathrm{mg}$, yielded a peak growth hormone level of $1.3 \mathrm{ng} / \mathrm{ml}$ (normal $>7 \mathrm{ng} / \mathrm{ml}$ ). Insulin hypoglycaemia $(0.1 \mathrm{U} / \mathrm{kg}$ iv) elicited no growth hormone response; however, there was a normal cortisol response with a peak level of $43.6 \mu \mathrm{g} / \mathrm{dl}$. GHRH-44 $(1.0 \mu \mathrm{g} / \mathrm{kg})$ showed a growth hormone peak of $5 \mathrm{ng} / \mathrm{ml}$ at 15 minutes, well below that of normal controls $(>10$ $\mathrm{ng} / \mathrm{ml}){ }^{4}$ GNRH $(100 \mu \mathrm{g})$ elicited a normal prepubertal FSH and LH response (peak FSH $12 \cdot 2$ $\mathrm{mIU} / \mathrm{ml}$ at 120 minutes, peak $\mathrm{LH} 13.7 \mathrm{mIU} / \mathrm{ml}$ at 30 minutes). TRH stimulation $(7 \mu \mathrm{g} / \mathrm{kg})$ yielded a normal peak TSH at $9 \cdot 1 \mathrm{IU} / \mathrm{ml}$. Based on these data, the patient has been defined as having isolated growth hormone deficiency.

\section{Discussion}

Holoprosencephaly is an embryonic malformation involving the forebrain and midface. There is wide range of variability in the manifestation of this abnormality. Brain malformations may range from an abnormally small forebrain with no hemisphereal development to normal brain differentiation. In addition, there are varying degrees of dysplasia of olfactory bulbs and nerves, optic nerves, and the corpus callosum. Facial anomalies have been noted to have a wide range of severity, from anophthalmia and cyclopia to mild hypotelorism or a single central incisor..$^{5}$ Recently, an ocular abnormality, coloboma, has been reported associated with single central incisor and growth failure. The mother of this patient had hyposmia and the authors pointed out that this case probably represents an autosomally dominant inherited form of holoprosencephaly. ${ }^{6}$ We believe that our patient with the ocular abnormality of microphthalmia, a single central incisor, and hypopituitarism, all individually known to be associated with holoprosencephaly, probably represents a mild manifestation of this abnormality. ${ }^{57}$ In fact, the sole clinical manifestation of holoprosencephaly may be a single central incisor.

The importance of recognising these milder manifestations of holoprosencephaly relates to the need for genetic counselling, as holoprosencephaly may be inherited as an autosomal dominant trait. ${ }^{689} \mathrm{~A}$ number of case reports describe a parent with minor manifestations of holoprosencephaly, that is, a single central incisor, hypotelorism, or hyposomia, and offspring with severe manifestations. ${ }^{689}$ Lastly, it is hoped that this report emphasises a new ocular abnormality associated with a single central incisor, and brings to the clinician's attention the wide spectrum of clinical abnormalities associated with holoprosencephaly.

We appreciate the cooperation of Dr S Kaplan of the University of California, San Francisco, in providing the GHRH-44 studies.

1 Rappaport EB, Ulstrom RA, Gorlin RJ, Lucky AW, Colle E, Miser J. Solitary maxillary central incisor and short stature. 7 Pediatr 1977;91:924-8.

2 Zuppinger KA, Sutter M, Zurbrugg RP, Joss EE, Oetliker $O$. Cleft lip and chorioideal coloboma associated with multiple hypothalamo-pituitary dysfunctions. $\mathcal{f}$ Clin Endocrinol Metab 1971;33:934-9.

3 Sadeghi-Nejad A, Senior B. Autosomal dominant transmission of isolated growth hormone deficiency in iris-dental dysplasia (Rieger's syndrome). 7 Pediatr 1974;85:644-8.

4 Rogol AD, Blizzard RM, Johanson AJ, et al. Growth hormone release in response to human pancreatic tumor growth hormonereleasing hormone-40 in children with short stature. 7 Clin Endocrinol Metab 1984;59:580-6.

5 Munke M, Emanuel BS, Zackai EH. Holoprosencephaly: association with interstitial deletion of $2 p$ and review of the cytogenetic literature. $A m \mathcal{J}$ Med Genet 1988;30:929-38.

6 Liberfarb RM, Abdo OP, Pruett RC. Ocular coloboma associated with a solitary maxillary central incisor and growth failure: manifestations of holoprosencephaly. Ann Ophthalmol 1987;19: 226-7.

7 Jones KL. In: Smith's recognizable patterns of human malformation. Philadelphia: Saunders, 1988:546-7.

8 Hattori H, Okuno T, Momoi T, Kataoka K, Mikawa H, Shiota $\mathrm{K}$. Single central maxillary incisor and holoprosencephaly. $A m$ f Med Genet 1987;28:483-7.

9 Berry SA, Pierpont ME, Gorlin RJ. Single central incisor in familial holoprosencephaly. $\mathcal{J}$ Pediatr 1984;104:877-80. 